\title{
Africa's Free Trade Area: An Assessment of the Readiness of Regional Economic Communities in Continental Integration
}

\author{
Joseph Kwabena Manboah-Rockson \\ Department of Research, Innovation \& Programs Development ORID), Catholic Institute of Business and Technology (CIBT), Adabraka, \\ Accra, Ghana \\ Email address: \\ jkrockson2004@yahoo.com

\section{To cite this article:} \\ Joseph Kwabena Manboah-Rockson. Africa's Free Trade Area: An Assessment of the Readiness of Regional Economic Communities in \\ Continental Integration. International and Public Affairs. Vol. 4, No. 2, 2020, pp. 53-62. doi: 10.11648/j.ipa.20200402.15
}

Received: December 30, 2029; Accepted: January 27, 2020; Published: September 16, 2020

\begin{abstract}
The recently launched (July 2019) African Continental Free Trade Area (AfCFTA), whose setup begun in 2015, is widely seen as the crucial driver for economic growth, industrialization and sustainable development in Africa. The concluded agreement establishing the AfCFTA provides rules that will govern the movement of merchandise and services across the continent. It sets up the institutional framework that will guide and regulate the CFTA implementation processes. There is a recognition that the current path of economic regionalism in Africa is encouraging but has serious fractures on the continent and the global trading system. In the attempt to achieve an overarching continental strategy for continuous development, there are vestiges of regional economic integration schemes, in the areas of multiple economic alliances, overlapping schemes, the non-implementation of protocols and many other fractures. In an attempt to alleviate these vestiges, the latest wave of continental innovation - AfCFTA - raises a long-standing conundrum for continental order: when are regional organizations useful, and even essential complements to the ends of continental governance for benefit, and when do they threaten or undermine the achievement of these goals? This paper's contention is that regionalism within Africa is anchored on many theories of integration, among them are functionalism, neo-functionalism, and intergovernmentalism, and based on the European integration experience. But drawing lessons from the enormous, political and economic as well as, security challenges confronting the African Union (AU) and the Economic Commission for Africa (ECA), how viable and ready can the RECs be used as 'vehicles' in support of the achievement of continental integration in Africa, when they are so 'gullible' themselves?
\end{abstract}

Keywords: Regional Economic Communities (RECs), "Building blocs”, "key pillars”, Continental Free Trade Area, AfCFTA, African Union

\section{Introduction}

The establishment of the African Continental Free Trade Area (AfCFTA) is the brainwork of the African Union Commission (AUC), which laid-out a roadmap through deliberations on the need for a free trade area for Africa from 2012 until its official launch in July of 2019. The time-table has been roughly 2 years behind the scheduled date of 2017 . About 44 countries are currently signatories to the AfCFTA's establishment framework which signifies the enthusiasm of the AU in intensifying economic regionalism. Launched at Kigali, the Rwandan capital in March of 2018, the AfCFTA came into effect on $30^{\text {th }}$ of May, 2019. This date is in conformity with the required legal 30-day provision in Article 23 of the Agreement, which enabled member countries to get the agreement ratified with their respective parliaments in accordance with the legal provisions of the AfCFTA Agreement. The provision was that: "at least a minimum of 22 countries must ratify the documents and deposit them with the African Union Commission to commence the AfCFTA" [1]. Population-wise, AfCFTA has a coverage of over 1.2 billion people across the 55 countries on the African continent and, according to WTO estimates, could be the largest free trade area in the world [1]. It is 
envisaged that AfCFTA will create a single continental market of goods and services and also consolidate the gains from regional integration, into a larger Customs' Union, with the free movement of the factors of production across the African continent. The creation of such a Customs' Union according to the United Nations Economic Commission for Africa (UNECA), "will increase intra-African trade by 52.3 percent, and is likely to double that figure, if further nontariff barriers are removed" [2]. In addition to the increase in intra-Africa trade, AfCFTA will also increase the competitiveness within the manufacturing sectors of the various Free Trade Areas (FTAs) and bring about economic diversification on the continent to enhance global trade. Additionally, there will be a harmonization of trade liberalization across FTAs and within the African continent if the commitments signed at Kigali, Rwanda are actualized to usher in the 90 percent target-removal of all tariffs on goods and services across board [3]. Despite the glamourous occasion ushering in the launch, there is an enormous skepticism and apprehension, looking back at the enthusiasm which witnessed the earlier establishments of the Regional Economic Communities (RECs) during the Lagos Plan of Action (LPA) of 1980 and its subsequent endorsement by the Abuja Treaty of 1991. The history of African economic regionalism can never be rewound and played back; but if that could be done at this time, the evolution of trade relations over the past forty to fifty years in Africa would not be something positive to write home about. All-over, are the challenges of snail-paced endorsements to agreements; the slow-paced ratifications and implementation of Treaty protocols associated with the respective RECs, and their ultimate cumulative (negative) effects on the various regional integration efforts [2]. The question therefore is; it is possible in the years immediately ahead to maintain a continent-wide free trade area without enormous challenges and upheavals? This paper is written along these lines: first to describe the origins of CFTA and regionalism in Africa and the early attempts at making it operational. The paper goes on to delineate the differences in opinion, at the regional level against the continental level, of the AU's plans to merge the eight (8) Regional Economic Communities (RECs) for the attainment of a larger Customs' Union. The latter parts of the paper are the dimensions of the AfCFTA; the realities and the prospects, as well as the conclusion.

\section{Background of AfCFTA}

The African Continental Free Trade Area (AfCFTA) is the latest wave of economic regionalism aimed at combining the eight (8) existing Regional Trade Agreements (RTAs) in Africa into a Continental Free Trade Area (CFTA). Continental trade facilitation is basically, four different measures that the African Union wants to implement, namely: port efficiency, streamline customs procedures within the ports, regulate ports' environment and encourage the use of e-business. In its entirety, trade facilitation involves the scaling down of transactional costs associated with institutional trade barriers by streamlining policies and procedures required in conveying goods from one country to another to make trade across borders faster, easier, cheaper and more predictable, whilst ensuring its safety and security. By estimates and projections, the CFTA is labelled as the largest Free Trade Area since the formation of the World Trade organization (WTO), which seeks to boost intraAfrican trade as the underlying objective. AfCFTA aims to create a single continental market for goods, services and the free movement of persons and capital, termed crucial for the development and interconnection of the continent. The AfCFTA is not a stand-along initiative; but an important milestone in Africa's regional integration efforts towards a united Africa. The AfCFTA is also a part of the broader economic integration and development agenda, initiated since independence by African leaders (Pan-Africanism), which first led to the formation of the defunct Organization of African Unity (OAU) in 1963 and its subsequent transformation into the African Union (AU) in 2002. The AfCFTA is aligned to the goals of other African Union programs which are crucial for the structural transformation, facilitation and industrialization through diversification and the development of regional value chains, as well as agricultural development [4]. Indeed, Africa's RECs have been charged by the African Economic Conference (AEC) to be the "key building blocs" for economic integration in Africa. Apart from this important charge, they are also charged to constitute as 'key actors,' working in collaboration with the African Union, in ensuring peace and stability in their respective regions. As the 'building blocs' and 'implementing arms' therefore, of the AU, the RECs are central to various transformative programs of the continent, including the New Partnership for Africa's Development (NEPAD), adopted in 2001, and the AU's Agenda 2063: "the Africa We Want," aimed at building a prosperous and united Africa; Action Plan for the Accelerated Industrial Development of Africa (AIDA), adopted in July 2014; the Action Plan for Boosting Intra-African Trade (BIAT), adopted at the $25^{\text {th }}$ Ordinary Summit of Heads of State and Government and the Comprehensive Africa Agricultural Development Programme (CAADP), established in 2003; and AU's First Ten-Year Implementation Plan, adopted at the $25^{\text {th }}$ Summit of the AU in June 2015. Similarly, beyond their roles in peace and security, the RECs are the main links, in collaboration with State Governments, Civil Society Organizations (CSOs), Non-Government Organizations (NGOs), and the AU Commission (AUC), to raise the living standards of the people of Africa and contribute towards the progress and development of the continent through economic growth and social development [2]. In short, the RECs are highly essential and instrumental for the effective implementation, financing, monitoring and evaluation of Agenda 2063 and its flagship programs, particularly at the regional levels for continental integration. The Pan-African CFTA, is a vision of "an integrated, prosperous and peaceful Africa, to be driven by its own citizens under its 50-year Structural Transformation Plan [3]. Deep integration is 
envisaged in terms of a single common market and economic and monetary union in Africa.

The CFTA is structured as follows: at the apex of the AfCFTA is (i) the High-Level African Trade Committee (HATC); (ii) the Conference of AU Ministers of Trade; (iii) the CFTA negotiations forum; the African Trade Forum; (iv) the African Business Council; (v) the African Trade Observatory; (vi) Monitoring and Evaluation Mechanisms; and (vi) the Trade Dispute Settlement and CFTA Agreement Enforcement Mechanism. The HATC comprise of Chairs of the RECs (Heads of State and Government of the AU), whose main role is to champion the promotion and establishment of CFTA. The creation of this structure emanates from the lessons drawn from challenges and drawbacks of RECs and trade liberalization in the past, for their lack of fortitude and synergy, during the $19^{\text {th }}$ Ordinary Session of the AU Summit in Addis Ababa in July 2012. At the Summit, these innovative ideas were concretized to task the AU Commission and the various Chief Executives of the RECs to commission baseline studies toward the establishment of the CFTA, as well as, to drive the process to fruition [4]. The CFTA has the following objectives: (i) to expand intra-African trade through better harmonization and coordination of trade among the various regional trading blocs across Africa; (ii) to bring about the competitiveness and market trade access both at the industry and enterprise levels within the RECs; (iii) to resolve the problem of multiple RECs, the overlapping membership of the RECs, and to establish a single continental market for goods and services, as well as, (iv) to ensure the free movement of factors of production and the establishment of a Continental Customs' Union (CCU).

Regional Economic Integration Progression

In regional economic integration progression, there are five (5) steps required, according to Bela Balassa, for Africa's regionalism to equal that of the European experience: (i) - Free Trade Areas are the basic forms of integration that a group of countries within a geographical setting can achieve. This occurs when the countries decide to remove all internal barriers to trade among themselves, in which each of them is free to decide what tariffs it wishes to apply to goods imported from or exported to a third party country. The other steps to achieve are: (ii) Customs Union - where countries within a geographical setting combine features of free trade area with common trade policies toward non-members countries; (iii) Common Market - whereby countries move forward to establish not only free trade in goods and services but also free movement of factors of production. (iv) Economic Union - where a group of countries commit to removing trade barriers, adapting a common currency, harmonizing tax rates, and pursuing a common external trade policy.; and (v) Political Union - where countries coordinate aspects of their economic and political systems [5]. No REC on the African continent has yet achieved step four (4); of the progressions in regional economic integration. While regional integration is increasingly viewed as a critical springboard toward economic diversification, there are significant trade costs and trade facilitation bottlenecks, which continue to dampen the viability of regional value chains in Africa. Indeed, trade facilitation is increasingly important for regional integration, competitiveness and development. One of the key questions that has always been raised about regional integration is; what strategy should be employed in the achievement of African continental integration? Several proposals have been made: some have proposed integration of the continent as a stand-alone strategy; some have proposed a top-down process; others have proposed it through the integration of the different African Economic Communities', the bottom-up process. But overwhelmingly at the Lagos Plan of Action (LPA) and the Abuja Treaty of 1991, the AU endorsed and embraced a bottom-up process with the RECs as the stepping stones to that continental integration.

\section{Theoretical Framework of the Study}

There are several volumes of scholarly debates as to whether regional economic integration comes by default following successful integration of countries within a geographical area, or whether it is something that has to be negotiated and agreed upon from the onset [6]. This question has been extensively examined by scholars such as Haas, Deutsch, Mitrany and many others [7]. Unfortunately, this debate has created several contentious political integration theories such as development theory, interdependence theory, theory of constructivism, functionalism theory, neofunctionalism theory and intergovernmentalism theory [3], among others, which can all be used in analyzing regional integration discourse. In this section, and in an attempt to attach theoretical rigor to the evolution and outcome of integration in Africa, we shall examine the theories of functionalism, neo-functionalism and intergovernmentalism to appraise the AU's latest invention - the reliance on RECs as the development tool of the $\mathrm{AU}$ in the establishment of the CFTA - due to its relevance to the integration processes.

\subsection{Functionalism}

Theories of regional integration refer to the sum of intellectual interpretations and or assumption of the processes, targets, and directions explored by states towards achieving collective and joint implementations of economic and political activities for the benefit of participating countries [9]. First is functionalism - functionalists theories emerged in the World War II years, in the writings of David Mitrany's book entitled; "A Working Peace System: an Argument for the Functional Development of International organizations" in 1943. Cited in Dinan, 2000 [9], Mitrany asserts that the international agreement and cooperation in specific technical and functional areas such as communications, postal services and health have been possible and feasible despite a fragmented political system after the first World War (19141918) and the second World War (1939-1945). These occurrences, according to him was possible because of technological advances in communication and transportation 
which in the twentieth century had made the world much more integrated in both physical and economic terms [8]. Further describing them as "functional international institutions;" Mitrany avers that their establishment has advanced economic and social welfare; where states were increasingly assigning more tasks to these institutions. And that as new functional agreements were put into practice, the scope of autonomous political action would become increasingly restricted; and that, as these institutions gained legitimacy and secured political support, they would (in time) supersede the nation state [8]. In Mitrany's wisdom therefore, world-wide political integration could be a product of economic, as well as, other forms of international agreements and cooperation. In furtherance of this argument, the basic rationale for the existence of any community, according to Mitrany, is welfare and security; and that once 'a moderate sufficiency' of what people want and ought to have is given them; they will keep the 'peace'(the people are satisfied) [8]. By this proposition, the functionalists argue that a peaceful international society is more likely to emerge through doing things together in "workshops and market places rather than by signing pacts in chancelleries" [8]. Therefore, sovereignty should be transferred to the new authority, which performs functional tasks. This way, all the units of the integration arrangement gain and are encouraged to display commitment [11]. Since "form" follows "functions" according to Dinan, 2000 [9], functionalism precedes with the basic assumption that regional integration ought to evolve gradually from disparate technical, social and economic spheres rather than political spheres, hence there should be no deliberate act to create a supranational entity to drive integration. International organization arranged according to the requirements of the task could increase welfare rewards to individuals beyond the level obtainable within the state; such that the rewards would be greater if the organization worked from small beginnings...that is, the functional approach to trap national governments into a system of interlocking cooperative ventures [10]. The major result of functional integration is that ' man' is weaned away from his loyalty to the state by the experience of fruitful international cooperation into technical and functional areas.

\subsection{Neo-functionalism}

Second is Neo-functionalism: the word 'neo' means a new 'version' of an old 'thing' or phenomenon. Indeed, the neofunctionalists took as their starting point the criticism of David Mitrany's functionalism theory from the 1940s which seeks to provide a closer integration without forcing countries to integrate too quickly. Neo-functionalism is associated with the economic and political goals, as well as the integration strategies of the founding fathers of the European Coal and Steel Community (ECSC); precisely, Jean Monnet's pragmatic approach to European integration. Jean Monnet's approach, which is said to have followed the neofunctionalism school's track to European integration, seeks to integrate individual sectors in hopes of achieving spillover effects to further the process of integration. By taking the criticism of David Mitrany's work on functionalism as a starting point from the 1940s [11], Ernest B. Haas and Leon Lindberg analyzed the achievements of the European Coal and Steel Community (ECSC) in 1951 and the European Economic Community (EEC) in 1957 as a means of the revival of functionalism. Neo-functionalism was developed in the second half of the 1950s and is the first 'classical' grand theory or narrative of the European Union. It is a theory of regional integration which builds on the work of Ernest Haas, an American political scientist and Leon Lindberg, also an American political scientist. Neofunctionalism downplays globalization and reintroduces territory into its governance. Whereas the functionalists challenged the state-centric worldview, focusing more on functions rather than forms, the neo-functionalists see the utopian nature of classical functionalism, reinstating political agency in the integration process (cited in Rosamond [12]). Also, neo-functionalism focuses more on the interdependence of, and the increasing demand for, cooperation between states to explain regionalism [13]. The most innovative aspects of the neo-functionalist theory is the 'spillover effects', which Haas defined as a situation where the creation and deepening of integration in one economic sector would create pressure for further economic integration in other sectors of the economy [14]. The consequence of "spillovers" is defined as the gradual entangling of national economies, increased interdependence between member states in one functional or issue area leading to interdependencies in other issue areas. This will make citizens of that territory, to eventually shift more and more of their expectations, to the supranational entity and if satisfied, will increase the likelihood that, such economic and social integration will 'spill-over' (pour-over) into political integration $[12,11]$. However, it remains a fact that neofunctionalist theories do not empirically explain the growing role of the states in relation to their over protection of their sovereignty and territoriality despite the desire to forge a political union. Using therefore, the latest innovation in regional integration within African RECs - the creation of the CFTA - symbolizes a fact that the AU and its allied organs have created an interdependence - where citizens of Africa, through their governments, are shifting more and more of their expectations to supranationality. This reinforces the fact that the CFTA exemplifies the "spill-over" of the historic Pan-African, and colonial relations amongst African countries that has existed prior to the formation of the defunct OAU and the current AUC. Relying more on issues pertinent to the development of Africa, the AUC is being accepted/trusted through intergovernmentalism in the gradual entangling of national economies leading to that path of achieving a continental (political) integration.

\subsection{Intergovernmentalism}

Third is intergovernmentalism: intergovernmentalism entails the notion that national governments are the main actors in the integration process. Proposed by Stanley Hoffmann and redefined by Andrew Moravcsik, intergovernmentalism is of the 
belief that governments determine the level and speed, as well as the ways and means of integration [12]. Its proposition is that member states and their governments are the main agents navigating regional integration processes through policy-making in order to protect their economic, as well as their national interests [15], [16-8]. The theory explains both periods of radical change in the European Union because of converging governmental preferences and periods of inertia because of diverging national interests. According to Moravcsik, there is a distinction of intergovernmentalism from realism and neorealism because of its recognition of the significance of institutionalization in global politics and the impact of domestic influences on government preferences [17]. The theory emerged as a critique of neo-functionalism and federalist predictions of the European Union turning into a State. However it was argued that "European integration was driven by the interests and actions of nation states" [19]. But before we examine the major issues confronting the RECs, it is imperative that we clarify the concept of regional integration by using the $\mathrm{AU}$ as a point of reference towards an overarching continental integration. What can probably be the deficiencies within the AU as the theoretical analysis progresses?

Indeed, African integration processes have been approached by various scholars without the intention of explaining away its theoretical considerations. Many tell stories of regional economic and political integration, only pertaining to their historical developments. But literature of such descriptive nature only deals with parts of the African integration problematique. For example Magliveras and Naldi [20], in their analysis of the AU, gives an overview of its objectives, principles, and institutions; without reference to the faults and cracks within the integration process; whereas Melber, [21] follows suite with an analysis of the "New African Initiative" and its relation to the AU. In both articles, they offer insights into the machinations or planning of the $\mathrm{AU}$, but barely mention the theoretical insights into the integration processes and delineating how the RECs were coordinating the continental agenda. Similarly, Manby [22], Omorogbe, [23] and Williams [24] talks about human interventions, peace and security and AU's role play. In their respective findings, they agree that there is lack of political will by African leaders, many of whom have a good reason, to keep stalling the programs and structures of the $\mathrm{AU}$ in monitoring good governance and performances of member states for their selfish gain [22]. In the limitations attributed to the commitments of the member states regarding deeper continental integration, one can observe how intergovernmentalism features: first, Ayittey, [25] describes African leadership as "leaderless" in the pursuance of neo-functionalism and away from intergovernmentalism approach by pointing at the influence of a strong ideology of continental Pan Africanism, which, he says, remains a dream and a strategy for addressing Africa's economic problems. Ayittey also bemoans the use of European theory of neo-functionalism as having been altered, for the Africana regional integration project, hence the setbacks encountered [25]. In a similar vein, Barbarinde,
[26] points to the need for the African Union Commission (AUC) to act as a stronger (supranational) institution, and to increase the involvement of the ordinary people in the integration process and 'develop its own resources' so as to create a real supranational level of governance. In the same direction, Muchie et al, [27] describes how a strong civil society is required to enhance integration processes by pointing to the low priority extended by nation states to the common idea of Pan-African unity, since "integration of Africa would have to prioritize the integration of Africa's people and not just states"[27]. Instead of following the Pan-African ideal of unity, Teiku [28] also agrees that the $\mathrm{AU}$ is not a supranational body and highly dependent on national leaders and that is why the entire $A U$ is a composite of the foreign policy interests and preferences of former Presidents Obansanjo of Nigeria, Mbeki of South African and a few influences of the late former president Maumar Ghaddafi of Libya. Also leaning in the direction of neo-functionalism is Olivier [29]; who blames the lack of non-functional approach to integration processes in Africa, and describes how the European case proves that small steps are required for progressive integration; and pointing to how the initial economic cooperation initiatives succeeded in Europe; but how the 'over-ambitious' political projects like the European Defense Community (EDC), failed in its tracks [29]. In their opposing viewpoints, Packer and Rukare concluded that economic integration in Africa is not feasible due to the divergence in the economies of member states [30]. In support of this assertions, Zank stresses two conditions for successful integration, which are absent in Africa's case: (i) the need for a consensus on basic constitutional principles (rule of law) and (ii) an identical socio-economic system. African countries, according to Zank do not exhibit, and still cannot be said to exhibit such broad array of compatible constitutional and economic models since attaining their respective colonial freedoms [31].

From these literature reviews of regional integration in Africa, one can quickly come to the understanding that African integration processes cannot be explained adequately, by a single theory. There is the need for the adoption of hybrid theories for understanding the convergence or divergence thereof; or at the very best, to ignore the straight application of European theories of integration to the failures and achievements of Africa and devise aspects of the existing integration theories that will serve to explain Africa's integration processes. This attitude will boost the morale of researchers, as well as lead to a revised theory as alluded to by Anichie, [32] in the "preponderance of a new theory of post-neo-functionalism, a synthesis of new-nationalism, postnationalism and humanism" [32]. In this way, African integration process, can be driven henceforth, by the RECs (regionalism towards continentalism), and anchored on democratic reforms; the continued struggle against military rule and authoritarian regime type and the insistence and continued agitation by Africans on the continent for multiparty democracy. Employing neo-functionalism and 
intergovernmentalism by the AU will be the appropriate way of getting the RECs to participate in the current regionbuilding effort. As a means of strengthening economic integration on the continent, member countries must continue to support the efforts of the AU and listen to the proposals made forth towards that continental goal of an integrated customs union that will lead to an overall common market and beyond for Africa. Like Anichie avers; this will usher in neo-neo-functionalism of post-neo-functionalism or postneo-nationalism that emphasizes the AU's commitment of an initial African integration based on (i) security matters through post-nationalism (Pan-Africanism), given the enormous security challenges still confronting the continent and (ii) a gradual progression, in phases on economic and political spheres with nation-building, and national development (through the RECs), of neo-nationalism and a combination of economic nationalism (through CFTA); and driven by the people or private sector rather than the government or the public sector through humanism [32].

\section{The Divergent Role (s) of the RECs in Continental Development}

The CFTA aspires to liberalize intra-African trade and inter-African trade across the continent and to build on the considerable successes already achieved within Africa's regional economic communities (RECs). The CFTA is more than a traditional free trade arrangement and contain many elements of single markets across the continent. Covering trade in goods and services, investment, intellectual property rights and competition policy, the CFTA is expected to jump start a process that will be complemented by other continental initiatives - the Protocol on Free Movement of Persons, Right to Residence and Right to Establishment, and a Single African Air Transport Market (SAATM) [2]. But whereas there are efforts by these RECs to strengthen sectoral cooperation and forge themselves into an 'arena of liberalization of trade in goods and services', the RECs have divergent goals and objectives, which defeats their respective roles in the regional integration process. The following are in respect of their divergence towards the continental agenda of the readiness of the RECs in projecting an overarching development strategy for continental integration.

First, there is a divergence in the manner and way the world's second-largest continent, comprising 55 member states of the African Union and eight (8) AU-recognized RECs see their trade liberalization legal frameworks. They should have been harmonized first before the launch of the CFTA. Secondly, there is a divergence on the part of RECs, who have not obtained the status of Tripartite Free Trade Areas within Africa. Will the rest of the RECs on the continent be encouraged to follow the examples of the East African Community (EAC), the Common Market for Eastern and Southern Africa (COMESA), and the Southern African Development Community (SADC) or remain as is? The third divergence is that, while Africa's regionalism places “developmental regionalism' at the center of its strategy for growth and structural transformation, current global trends show a growing skepticism towards regional integration and trade agreements [33]. The fourth divergence lies at the heart of Africa's development strategy which recognizes the need for trade liberalization to precede, and at the same time, addressing supply capacities to promote structural transformation. The CFTA's approach is not only unconventional, but also sidesteps many aspects of the carefully defined schedule of the Abuja Treaty's progression towards the African Economic Community [33]. The biggest task are contextualized legal issues of the CFTA Agreement that may be at odds with the Abuja Treaty in respect of the roles of RECs at the regional level and strategic publicprivate partnerships at the national levels. The fifth divergence is in respect of parallel roll-out of the Boosting intra-African Trade (BIAT) Action Plan and the CFTA against the constraints and challenges thereof. The sixth divergence is the distributional impacts at the subnational level and across vulnerable groups. The CFTA initiative must be a means of eradicating poverty, not creating disparities; and should consider different economic configurations so that the fruits of CFTA can be shared equitably across the continent to result in a win-win approach to regional integration. The final divergence has to do with the CFTA itself. The CFTA is touted as a developmental approach to regional integration but the progress of the various FTAs are already slow due to inadequacy of institutional framework for realization of important objectives. Will the CFTA have an adequate financing mechanism, if not; this can pose obstacles to factor mobility like labor, capital and enterprise and result in the lack of trade information systems across the continent [34]. More to these above, there has been rhetoric of continental unity and regional integration which are not matched by practical actions. The political will and enthusiasm is weak and slow. Extraordinary and Ordinary Summits of Heads of State and Government are only avenues for grand political pronouncements and agreements at the continental level; these pronouncements require implementation and support at the national level by state governments [35-38]. In fact, someone or a group of leaders within the Assembly of Heads of state and government should take up the mantle of leadership and drive the integration process. While there is the need to establish the Pan-African FTA, which is unambiguous, the African Union must remain steadfast, resolute in its relations with its member states to capture this moment and instill the discipline required to ensure that the various programs geared towards the launch of the CFTA are successful to accomplish that overarching goal of consolidating its member countries toward continental integration.

\section{Current State of Affairs, Realities and Prospects}

Regional cooperation in African began in earnest with the 
Abuja Treaty in 1994 stemming from an earlier aborted Plan under the Treaty of Lagos in 1980. The Abuja Treaty, also known as the AEC Treaty, set ambitious and wide ranging objectives that reflected the need to accommodate heterogeneity of interests across the continent. The emphasis was that incremental progressions would be achieved within the regional economic communities (RECs) that will result into a continental (political) integration. First the RECs were officially recognized by the African Union through the Heads of State and government as the 'building blocs' of continental integration. They were eight (8) in number laid out as follows; the Arab Maghreb Union (AMU/UMA), the Economic Community of West African States (ECOWAS), the East African Community (EAC), the Intergovernmental Authority on Development (IGAD), the Southern African Development Community (SADC), the Common Market for Eastern and Southern Africa (COMESA), the Economic Community of Central African States (ECCAS) and the Community of Sahel-Saharan State (CEN-SAD). Secondly, they were charged with six-stage variables, spanning thirty-four years toward the achievement of 'an African Economic Community by 2028.' The objectives were enumerated as follows: stage 1 - to strengthen existing RECs and establish new RECs in regions where they did not exist by 1999; stage 2 - to ensure consolidation within each REC (gradual removal of tariff and non-tariff barriers) and harmonization between the RECs by 2007; state 3 - to establish Free Trade Areas (FTAs) and Customs Union (CUs) by 2017; stage 4 to coordinate and harmonize tariff and non-tariff system among the RECs with a view to creating a continental CU by 2019; stage 5 - to create an African Common market (ACM) by 2023 ; stage 6 - to establish the African Economic Community, including an African monetary Union and a PanAfrican Parliament by 2028. Notwithstanding all these, the RECs were to support the AU and the ECA, in spite of the configuration of highly heterogeneous states in African along multiple dimensions.

\subsection{The Realities}

The African continent is a mess in terms of the enthnolingustic, religious, cultural and artificial boundaries, which has halved tribes, disregarded natural boundaries like rivers or mountains, and has made it even more harder, a great challenge for countries wishing to integrate to accelerate industrialization [39]. Indeed, the RECs have been operating since 1994 (the Abuja Treaty), as the driving force for integration processes across the African continent. The RECs have been dealing with small, fragmented and isolated economies with unequal distribution of geographic characteristics. With these limitations and many more in their respective regions, the RECs have not been able to make a compelling case for integration on a regional basis yet, as they are not able to reduce the thickness of borders to exploit scale economies and other benefits of that geographical closeness through integration. Indeed, there has been an abysmal performance by these RECs in their effort to assist the African Union to accomplish integration goals and objectives set for them since 1994 in Abuja, Nigeria. The case is amplified when you run down the table below; as only three (3) of the eight (8) recognized RECs have both a FTA and CU ECOWAS, EAC and COMESA; but even then, they are with varying degrees of implementation and cannot be felt by the ordinary citizen of the community. For instance, there is nothing like the free movement of people or goods as people crossing the borders are searched thoroughly; some forced to pay money and others having to force their way through illegal crossings along the borders. For instance, Nigeria has locked its borders to Ghana, Benin, Togo, Niger and Burkina Faso during the early part of 2019 last year and is yet to open them to free movement of the factors of production, with an excuse that it was monitoring Boko Haram and the smuggling of rice from the country. More to the point, the RECs are progressing at different speeds across the various components of the Abuja Treaty, making the EAC, the only REC that has made significant progress across board.

Table 1. Implementation Stages of Region and Economic Communities (RECs) in Africa.

\begin{tabular}{llllll}
\hline REC & FTA & CU & SM & COUNTRIES FM Protocol & EMU \\
\hline ECOWAS & & $\mathrm{X}$ & All 15 & $\mathrm{X}$ \\
EAC & & & 3 out of 5 & $\mathrm{X}$ \\
COMESA & & $\mathrm{X}$ & Only Burundi has ratified & $\mathrm{X}$ \\
ECCAS & & $\mathrm{X}$ & $\mathrm{X}$ & 4 out of 11 & \\
SADC & & $\mathrm{X}$ & $\mathrm{X}$ & 7 out of 15 & $\mathrm{X}$ \\
AMU & $\mathrm{X}$ & $\mathrm{X}$ & Oout of 5 & $\mathrm{X}$ \\
IGAD & $\mathrm{X}$ & $\mathrm{X}$ & No Protocol & $\mathrm{X}$ \\
CENSAD & $\mathrm{X}$ & $\mathrm{X}$ & Unclear & $\mathrm{X}$ \\
\hline
\end{tabular}

Source: Adapted for explanation from - Innovation competitiveness and Regional Integration: [2].

Furthermore, a report of the above table indicates the following: As earlier alluded to, only three of the eight recognized RECs have both a FTA and Custom Union, but in various stages or progression. Even though the Free Trade Area (CFTA) does not feature explicitly in the African Union schedule of items to be accomplished, in accordance with the AEC, the CFTA has become an intervention in the right direction to step up the continental (political) agenda.
Afterall, among the wide range of possible options for continental integration on the continent is a choice of an incremental intergovernmental development cooperation paradigm, driven along sectoral lines. This brings about the unfettered state-driven and linear development approach; as well as, the supranational regional institutional arrangement being applied by the African Union (AU) and the Economic Commission for Africa (ECA) to the integration processes. 
These approaches to regional integration, however offer different permutations in relation to Africa's historical context, the nature of African politics, the character and type of our institutions, and the political economy of development of the countries on the African continent [39].

\subsection{The Prospects of AfCFTA}

The establishment of the AfCFTA is differentiated by the fact that it is the creation of independent African countries. The idea of a continental Africa has been, and still a propagation via the idea and philosophy of Pan-Africanism ideology and reactions to racism, slavery, colonialism and neo-colonialism on the continent. From the OAU formation in May 1963 at Addis Ababa, Ethiopia were the objectives to rid the continent of the vestiges of colonization and apartheid, to promote unity and solidarity among African states; to coordinate and exalt cooperation for development and to safeguard the sovereignty and territorial integrity of African nations through the United Nations Charter. Despite the quest for solutions to the continent's numerous problems, there has been the push for the achievement of economic integration from the time of the OAU in 1963 to the Constitutive Act establishing the African Union (AU) of 2002. Africa is the least integrated regions in the world and as such, wants to use economic integration as one policy lever that can help increase and sustain its growth. Africa is a huge continent - as large as the United States of America, Mexico, China, India, Japan, the Western and Eastern Europe combined - but it remains a purposeful-driven bloc of 54 countries of various sizes, many of which has very little economies; six of which are landlocked and have no access to seaports [40]. As a result, Africa is considered the most expensive region within which to transact business in the world because infrastructure is insufficient - no good bridges, roads, airports, seaports and warehouses. There is no wonder that intra-regional trade in Africa is the lowest in the world, and for a decade, has remained at about 10 percent compared to 30 percent in South East Asia and 60 percent in the European Union [40]. Therefore, the launch of the AfCFTA by the AU is a good move to reduce the burden posed by WTO's Trade Facilitation Agreements, which provides a new global benchmark for custom and border procedures, to help firms move goods more quickly, reliably, and cost effectively across borders [41]. Similarly, the creation of the CFTA and the putting into practice of the Action Plan on boosting IntraAfrican Trade (BIAT), provides a comprehensive framework to pursue a developmental regionalism strategy based on the spill-over, from the establishment of one function to the other. The former is conceived as a time bound project, whereas BIAT remains a continuous program to double intra-African trade flows from January 2012 to January 2022. More so, the CFTA has been established as a continental system to derive economic growth on the African continent and would ever be remembered as the boldest attempt by the AU to arrest the fundamental causes of Africa's continuous economic decline. These include the regional disparities of RECs, the inequalities and intractable problems of politicization that has often created tensions and apprehensions within the respective RECs in view of our globalized world. Thus Africa wants a lessening of the high degree of external dependence on forces of globalization as a precondition for achieving basic structural development goals that most African countries want at this particular time [42]. Negotiations under the CFTA have been aimed at not unravelling what has already been accomplished, but rather preserving exiting trade agreements between countries "as is," while promoting new agreements between the countries that do not have existing preferential agreements or negotiations in place. The CFTA will help ensure the progressive elimination of tariffs; however, where there are still gaps in non-tariffs barriers, an agreement would help to establish rules to manage non-tariff barriers. The agreement will facilitate cooperation on technical barriers to trade and sanitary, as well as phyto-sanitary measures [40]. The CFTA can stimulate Africa's industrial development and employment, as well as enhance investor confidence on the continent. Even though the RECs have the capacity to assist propel this vision of the $\mathrm{AU}$, it is handicapped by various divergences; mostly the financial independence to implement the CFTA without donors' support. In summary, the establishment of the AfCFTA signifies the readiness on the part of governments to embrace legally-based institutions and hard rules to underpin the expansion of markets. In the AU's utilization of the RECs as the building blocs for continental (political) unity in Africa, there is an increasing number of economic agreements and the growing number of institutions with much political leverage to legally formalize cooperation at the continental level. But my worry is whether the economic integration already achieved within the RECs will encourage, and by extension, bring about a fledging CFTA, and also ensure a deliberate deepening of institutions within member states to grace regional integration.

\section{Conclusion}

From the assessment of the literature so far, there is the attempt by the African Union to use the RECs as an overarching development strategy for continental integration. Also from the afore-discussed integration theories, we can carefully capture the essence that African integration processes are uniquely European centric in terms of their intended progression. The realities of the European integration are that there are quantifiable successes of regional integration, which motivated the initial six ECSC member states to drive for an expanded integration scheme cutting across the economic sectors in Europe. The European Union initiated in 1951, with the creation of the European Coal and Steel Community (ECSC). The creation of the European Economic Community followed (1958) with a treaty signed in 1957 by Belgium, France, Italy, Luxembourg, the Netherlands, and the then West Germany (now Germany). This was informally known as the Common Market of the EEC. The Treaty further established the Common Assembly and the 
European Court of Justice; the European Commission and the Council of Ministers for the new communities. Even though the United Kingdom refused to join the Community, the EEC became the rallying point for external tariff, and common market. The European Union can today boast of twenty-eight (28) member states with a wide scope in its regional and defense polices, including the Common Foreign and Security Policy (CFSP) and has adopted the Euro (a common currency), successfully from January of 2002, as well as the establishment of the European Central Bank. During these times, and through various polices, the Community has developed its external relationship with former French colonies in the Yaoundé Accords of 1963, the Lome Conventions of 1975, 1980, 1985 as well as the Cotonu Partnership Accord of 2000 among many other agreements. Even though the United Kingdom (Britain) is due to leave the Union by January 31,2020 , it is not perturbed. The EU is consolidating its gains from regional integration and proving the fruitful gains from the Union. But in terms of the realities facing the AU, the RECs have not been able to accomplish much from 1994, when the AEC Treaty, also known as the Abuja Treaty came into force, charging RECs "as the building blocs," as well as the 'engines' that would propel continental integration. In fact, the African integration project has remained a head-tobottom approach or what one may call integration from above. The African Union Commission is yet to be given the free hand to stir the affairs of regional or continental integration without political or domestic interference. Whereas the European Union was able to start from the bottom-to-top approach; to develop a single market, realize pass-port controls within the 'Schengen Area' and are generally experiencing the so-called "spill-over" effects via enactment of common foreign and security policies; the "spillover" effects within Africa's regional integration are largely an elusive phenomena for now. But if the African Union, with the assistance of the RECs are yet to forge that kind of machinations for an effective sub-regional integration, it requires leadership; an efficient and inclusive institutional architecture; a robust monitoring and evaluation framework; and innovative financing for much needed investments in infrastructure and productive areas of RECs. For AfCFTA to succeed, there must be an expansion in intra-African trade; which is key to creating decent jobs, improving productivity, increasing incomes, and reducing economic vulnerability and risks within the RECs. And if the AU gets the implementation of CFTA right, it will be the game-changer that has been anticipated for a long time to bring an end to the social and economic conundrums.

\section{References}

[1] World Trade Organization. List of all RTAs. Http://rtais.wto.org/UI /PublicAIIRTAlist.aspx/ 2019.

[2] United Nations Economic Commission for Africa. Briefing on the Key Messages and Recommendations of ECA's Regional Integration Flagship Reports, Marrakech, Morocco, 2019.

[3] Bolanos, A. B. A step further in the theory of regional Integration. A look at the Unasur's integration strategy. Working Paper. GATE, 2016-17. Available at: https://halshs.archieves. Ouvertes. Fr/halshs-0315692/docs. [Accessed on: 9 August, 2016].

[4] African Union. "Africa CDC Centre for Disease Control and Prevention: Safeguarding Africa's Health.” https://.au.int/en/africacdc, 2019.

[5] Balassa, Bela. The Theory of Economic Integration, London, Allew and Unwin, 1961.

[6] Brou, Daniel and Ruta, Michele. "Economic Integration, Political Integration or Both?" Journal of the European Economic Association, 2011, 9/6, p. 1143-1167.

[7] Gilpin, Jean. Global Political Economy. Understanding the International Economic Order. Princeton University Press. 2001.

[8] Mitrany, David. "A Working Peace System: An Argument for the Functional Development of International Organization", excerpt in Mettle Eilstrup-Sangiovanni (2006), Debates on European Integration. Palgrave Macmillan, 1943. P. 37-42.

[9] Dinan, Desmond (ed). Encyclopedia of the European Union. Boulder/London: Lynne Rienner, 2000, p. 245.

[10] Aworawo, D. Integration, Economic Globalization and Africa's Development: the Experiences of Nigeria and Botswana. The European Journal of Development Research, 2009, Volume. 21, No. 2, p. 26.

[11] Dosenrode, Soren. Federalism Theory and Neo-functionalism: Elements for an Analytical Framework. Perspectives on Federalism, 2010, Vol. 2 (3), p. 21.

[12] Rosamond, Ben. Theories of European Integration: Hampshire, Palgrave. Macmillan, 2000, P. 55.

[13] Hurrel, Andrew. Explaining the Resurgence of Regionalism in World Politics. Review of International Studies 21 (4): 331358,1995 , p. 331-335.

[14] Haas, Ernst Bernard. "The Uniting of Europe"” Political, Social, and Economic Forces 1950-1957. Stanford: Stanford University Press, 1968, p. 283-287.

[15] Hoffman, S. Toward a Common European Foreign and Security policy? Journal of Common Market Studies, 2000, 38 (2), p. 189-198.

[16] Taylor, Paul. The European Community and the State: Assumptions, Theories, and propositions. Review of International Studies 17 (1), 1991, P. 109-125.

[17] Moravcsik, Andrew. and Nicolaidis, Kalypso (1999). Explaining the Treaty of Amsterdam: Interests, Influence, Institutions. Journal of Common Market Studies, Vol. 37, No. 1 March, 1999, p. 59-85.

[18] Moravcsik, Andrew. Negotiating the Single European Act: National interests and conventional statecraft in the European Community. International Organization 45 (1). 1991, P. 1956.

[19] Hix, Simon. The Political Systems of the European Union. Basingstoke: Macmillan, 1999. 
[20] Magliveras, Konstantinos M. \& Naldi, Gino J. The African Union: A New Dawn for Africa? The International and Corporate Law Quarterly. 2002, Volume. 5 (2), p. 415-425.

[21] Melber, Henning. The New African Initiative and the African Union. Nordiska Afrikainstitutet, 2001, Volume. 25, p. 3-31.

[22] Manby, Bronwen. The African Union, NEPAD, and Human Rights: The Missing Agenda. Human Rights Quarterly. 2004, Volume 26 (4), p. 983-1027.

[23] Omorogbe, E. Y. Can the African Union Achieve Peace and Security? Journal of Conflict \& Security Law, 2011, Volume $16(1)$, p. 35-62.

[24] Williams, P. D. The Peace and Security Council of the African Union: Evaluating an Embryonic International Institution. Journal of Modern African Studies, 2009, Volume 47, (4), p. 603-626.

[25] Ayittey, George B. The United States of Africa: A revisit: the ANNALS of the American Academy of Political and Social Science, 2010, Volume 633, p. 86-102.

[26] Babarinde, Olufemi (2007). The EU as a Model for the African Union: the Limits of Limitation. Jean Monnet/Robert Schuman Paper Series, 2007. No. 7/2. p. 11.

[27] Muchie, Mammo; Habib, Adam; Padayachee, Vishnu. African integration and Civil society: the case of the African Union Transformation: Critical Perspectives on Southern Africa, 2006, Volume 61, p 3-24.

[28] Teiku, T. K. Explaining the Clash and Accommodation of Interests of Major Actors: in the creation of the African Union. African Affairs, 2004, Volume 103, p. 249-267.

[29] Olivier, Gerrit. Regional Integration in Africa: A Political perspective. Johannesburg, South Africa. Centre for African and European Studies, University of Johannesburg, 2008.

[30] Packer, Corinne A. and Rukare, Donald. The New African Union and its constitutive Act. The American Journal of International Law, 2002, Volume 96 (2), p 365-379.

[31] Zank, W. 'Comparative European View on African Integration': Why it has been much more difficult on African than in Europe'. Working paper 4 (CCIS Research Series, Aalborg University, 2007.

[32] Anichie, Ernest Toochi. Post-neo-functionalism. Pan Africanism and Regional integration in Africa: Prospects and Challenges of the Proposed Tripartite Free Trade Area (TFTA). A paper presented at the fifth Toyin Falola international Conference. Titled: Yoin Falola Annual Conference on Africa and Africa's in Diaspora (TOFAC). Held on July 2-4, 2015 at University of South Africa (UNISA), Pretoria, South Africa. Under the Auspices of Thabo Mbeki African Leadership Institute. Aniche, Ernest Toochi. Problematizing Neofunctionalism in the Search for a New Theory of African integration: the case of the proposed Tripartite Free Trade Area (T-FTA) in Africa. Developing Country Studies, 2014, 4 (2), p. 128-142 (TMALI), 2015a.

[33] United Nations Commission on Trade and Development. International Trade in goods and services. UNCTADstat Database, UNCTAD, Geneva, 2018.

[34] Nkuepo, Henri. Joel. Africa's Continental Free Trade Area. A closer look at the 2012 African Union's Plan for Boosting Intra-African Trade. Washington, D. C. George Washington University Law School \& University of Iowa School of Law, 2012.

[35] Disenyanai, Tsidiso. Towards an EAC, COMESA and SADC Free Trade Area. Issues and Challenges. South African Institute of International Affairs [SAIIA], October 2009.

[36] Musonda, M. J. The COMESA Customs Union: Challenges and Opportunities in Inside Southern Africa Trade. Southern African Global Competitiveness Hub. 15, p. January, 2009. P. 10-11.

[37] Woolfrey, Sean. Industrial Development in the Tripartite Free Trade Area. In Free Trade Area - Towards a New African Integration Paradigm? Stellenbosch. TRALAC, 2012.

[38] Anichie, Ernest Toochi, Problematizing Neo-functionalism in the Search for a New Theory of African integration: the case of the proposed Tripartite Free Trade Area (T-FTA) in Africa.

[39] De Melo, J. Regional Integration arrangement in Africa: Is Large Membership the Way Forward? Helsinki: Brookings Africa in Focus Blog, 2015.

[40] United Nations Economic Commission for Africa. "Key pillars of Africa's Regional Integration", UN Economic Commission for Africa. Addis Ababa, 2019.

[41] Mold, Andrew and Mukwaya, Rodgers. The Effects of the Tripartite Free Trade Area. Towards a New Economic Geography in Southern, Eastern and Northern Africa? Centre for Research in Economic Development and International Trade Paper 15/04, 2015, p. 33.

[42] Manboah-Rockson, Joseph Kwabena (2000). Regionalism and Integration in sub-Saharan Africa: A Review of Experiences, Issues and Realities at the Close of the Twentieth Century. Innovation: Journal of Politics. University of Calgary, Canada. 2000, Volume. 3. P. 47-68. 